\title{
China's Longest Campaign: Birth Planning in the People's Republic, 1949-2005
}

\author{
by Tyrene White \\ Ithaca, NY: Cornell University Press, 2006 \\ ISBN 978-0801444050 \\ Softcover, $\$ 24.95,297$ pp.
}

\section{Reviewed by Quanbao Jiang}

Institute for Population and Development Studies
School of Public Policies and Administration, Xi'an Jiaotong University (China) recluse_jqb@126.com

During the three decades that followed the founding of the People's Republic of China (PRC), many scholars explored the impact of high fertility on economic development. Nelson (1956) suggested there would be a low-level equilibrium trap for underdeveloped countries, namely a stable equilibrium level of per capita income at or close to subsistence requirements; cycles of poverty could then result due to stagnation of per capita investment as population grew rapidly, even though the capital stock accumulated. Coale and Hoover (1958) pointed out that extra births under high fertility would engulf the total product. A period of two to three decades of reduced fertility would result in fewer dependents and less of the total product assigned to consumers, and thus a higher average economic level. This was treated as a classic theory and a solid foundation for controlling birth control. In order to prevent per capita GNP from declining, three percent of total GNP would have to be invested in fixed capital for each percentage point increase in population (United Nations 1971). Many studies were devoted to the negative correlation between high fertility and economic development. These studies generated interest in the need for a population policy and the optimal design of such a policy (Birdsall 1977). With the publication of The Population Bomb (Ehrlich 1968) and The Limits to Growth (Meadows et al. 1972), a sound population policy received even stronger advocacy.

Even though China, the world's most populous nation, was estranged and cut off from the outside academic community, it experimented remarkably with its fertility. Tyrene White's 2006 book, China's Longest Campaign: Birth Planning in the People's Republic, 1949-2005, is a very ambitious effort to elucidate the vicissitudes of this experiment with birth planning after the founding of the PRC. Based on reliable documentary evidence and numerous interviews with Chinese citizens, grassroots cadres, and officials, White examines the course of the long campaign that was premised on the radical idea of engineering fertility and rationing children through the use of strict birth limits. She illuminates why and how China could undertake such an unpopular policy of transforming a voluntary birth control program into a mandatory program and, most importantly, describes how such a program could survive and be intensified.

The 297-page book includes nine chapters, as well as references and indexes. In the introductory chapter, entitled "The Collectivization of Childbearing," White presents the focus of the book, namely, why the Deng Xiaoping regime chose population control and such a strict rationing method, as well as the means of enforcement, and the state's imperviousness to peasant resistance. The author explains her choice of the term "birth planning" rather than other possible terminology. The second chapter explores the origins of birth planning before 1960 under Mao's regime. In the mid-1950s, even though the anti-natalist policy was adopted, with Zhou Enlai and others instituting a program and plan, it was not strictly implemented without Mao's personal endorsement. Chapter 3 is devoted to the transition from loose birth control during the Great Leap Forward period and the Cultural Revolution under Mao's regime to the strict birth planning under Deng's regime. In chapter 4 the author presents a vivid picture of 
the process of mobilization for such an unpopular campaign, and the methods used to achieve the birth planning target. Chapter 5 introduces how the rural reform of decollectivization affected the one-child campaign, and chapter 6 covers the notorious mass sterilization campaign, and how it was largely given up due to the repudiation of work style, and rural unrest and by a Central Document issued in 1984 which largely changed the overzealous and harsh operation of the government family planning offices. Chapter 7 illuminates the five basic types of resistance to birth planning: four standard strategies, namely, evasion, collusion, cover-up, and confrontation, and an unusual accommodation method, that is, infant abandonment and sex-selective abortion. Chapter 8 reviews the revitalization of campaign style birth planning that began in the late 1980s after a slight relaxation in the mid-1980s. White explores this campaign's limitations and outlines the progress toward reform in both theory and practice. In the last chapter, she studies the campaign as a political institution, and explains the state-peasant struggle and the price of China's attempt to engineer its fertility transition.

The most striking feature of the book is its political science perspective. While China's birth planning policy is usually criticized as bringing about political, biological, and social upheavals, White elucidates the process, from the beginning to 2005 , clearly demonstrating how the state claimed domination over the personal behaviour of its people, and sovereignty over the production of life. The book features a wealth of documentary and interview information. It is surprising that even in the 1980s, White, as a foreigner, was able to interview villagers. As a result, we learn not only about the birth planning policy, but also about many other aspects of Chinese political and social life.

Although White intends her book to be a political analysis, rather than a demographic analysis, of China's population, I would have liked to have seen more discussion of the demographic consequences of the campaign. Since the 1970s, the total fertility rate has fallen dramatically, partly because of the stringent family planning policy. By 2000 the total fertility rate had dropped to 1.4-1.6, and preliminary results of the 2010 census indicate that the total fertility rate has fallen below 1.5 children per couple. A country with a total fertility rate of less than 1.5 may fall into the low fertility trap, and policymakers may turn to a pronatalist campaign again, as have many European countries, Japan, and South Korea. The drop in fertility in China has been a demographic revolution, and is to a considerable extent attributable to China's population policy, a policy that has reframed and restructured Chinese society. Already by the mid-1980s, far-sighted demographers predicted that if the one-child policy were to achieve complete success, its side effects would become very serious (Bongaarts and Greenhalgh 1985; Greenhalgh and Bongaarts 1987). The 1980 Open Letter refuted concerns about some side effects, such as possible shortfalls in manpower, rapid population ageing, and distortions in the sex ratio. Today China is indeed confronted with these challenges and others. I would have liked to see a review of these consequences of the family planning program. White emphasizes the peasant resistance to the programs, but she doesn't investigate divergent voices from Chinese academia. For example, Liang Zhongtang objected to the stringent birth control at its onset. From 2000, Gu Baochang, Wang Feng, Peng Xizhe, Guo Zhigang, Zheng Zhenzhen, and Cai Yong began to examine China's low fertility and birth planning policy. And in 2004, eighteen Chinese scholars, most of whom are leading demographers, signed a petition to the Central Committee of the Chinese Communist Party, the State Council, and many relevant ministries, appealing for the birth planning policy to be weakened. I understand that before White's publication, not many people are familiar with their work, but I think the work of these scholars should be credited.

Despite the somewhat formidable title and the above reservations, I feel that the volume forms a significant addition to the literature in a vitally important area of China studies. Its analysis of China's birth planning should be of general interest to scholars, policymakers, and the public. I strongly recommend the book, especially to Chinese readers. China has been obsessed with campaigns, and one may speculate whether the birth planning campaign will be followed by a long pronatalist campaign in the foreseeable future.

\section{References}

Birdsall, N. 1977. Analytical approaches to the relationship of population growth and development. Population and Development Review 3(1-2):63-102.

Bongaarts, J., and S. Greenhalgh. 1985. An alternative to the one child policy in China. Population and Development Review 11(4):585-617. 
Coale, A.J., and E.M. Hoover. 1958. Population Growth and Economic Development in Low-Income Countries. Princeton: Princeton University Press.

Ehrlich, P.R. 1968. The Population Bomb. New York: Ballantine Books.

Greenhalgh, S., and J. Bongaarts.1987. Fertility policy in China: Future options. Science 235(4793):1167-1172.

Meadows, D.H., D.L. Meadows, J. Randers, and W.W. Behrens III. 1972. The Limits to Growth. New York: Universe Books.

Nelson, R.R. 1956. A theory of the low-level equilibrium trap in underdeveloped economies. American Economic Review 46(5):894-908.

United Nations. 1971. The Developing Countries in the 1960s: The Problems of Appraising Progress. World Economic Survey 1969-1970. New York: United Nations. 